THE EGONOMICS OF NATURAL RESOURCE DEPLETION 


\title{
The Economics of Natural Resource Depletion
}

\author{
edited by \\ D. W. PEARGE \\ Professor of Political Economy \\ University of Aberdeen \\ assisted by \\ J. ROSE
}

Director, Institute of Environmental Sciences and Principal, Blackburn College of Technology and Design

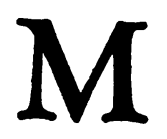




\section{(C) The Macmillan Press Ltd 1975}

All rights reserved. No part of this publication may be reproduced or transmitted, in any form or by any means, without permission.

First edition 1975

Reprinted 1978

Published by

THE MACMILLAN PRESS LTD

London and Basingstoke Associated companies in Delhi Dublin

Hong Kong Johannesburg Lagos Melbourne

New Tork Singapore and Tokyo

ISBN 978-0-333-18276-5

ISBN 978-1-349-15577-4 (eBook)

DOI 10.1007/978-1-349-15577-4

This book is sold subject to the standard conditions of the Net Book Agreement.

The paperback edition of this book is sold subject to the condition that it shall not, by way of trade or otherwise, be lent, resold, hired out, or otherwise circulated without the publisher's prior consent in any form of binding or cover other than in which it is published and without a similar condition including this condition being imposed on the subsequent purchaser. 


\section{CONTENTS}

Preface and Acknowledgements

I EDITORIAL INTRODUCTION 9

2 THE DEPLETION OF ENERGY RESOURCES $2 \mathrm{I}$

Colin Robinson, Professor of Economics, University of Surrey

3 SOME ISSUES IN THE CURRENT DEBATE ABOUT ENERGY AND NATURAL RESOURCES

A. J. Surrey, Senior Research Fellow, and William

Page, Research Fellow, Science Policy Research

Unit, University of Sussex

4 COMMENTS ON THE PAPERS BY

ROBINSON, AND SURREY AND PAGE

Michael Common, Lecturer in Economics,

University of Southampton

5 DISGUSSION BY CONFERENGE DELEGATES 8I

6 OPTIMAL DEPLETION OF A REPLENISHABLE RESOURCE: AN EVALUATION OF RECENT CONTRIBUTIONS TO FISHERIES ECONOMICS

John Butlin, Lecturer in Economics, University of Manchester

7 DISCUSSION BY CONFERENGE DELEGATES

8 ECONOMIG ASPECTS OF NATURAL RESOURCE DEPLETION 9 I 
IO COMMENTS ON THE PAPERS BY BUTLIN, HEAL, AND KAY AND MIRRLEES

Peter Simmons, Lecturer in Economics, University of Southampton

I I RESOURCE CONSERVATION AND THE MARKET MECHANISM

Ivor Pearce, Professor of Economics, University of Southampton

I2 DISCUSSION BY CONFERENGE DELEGATES 204 Notes 


\section{PREFACE AND ACKNOWLEDGEMENTS}

With the exception of one essay by Professor Ivor Pearce, the papers in this book are slightly modified versions of ones given at a conference on the economics of natural resource depletion which took place at the Royal Institution, London, on 16 January 1974. The conference was organised jointly by the U.K. Environmental Economics Study Group, an organisation sponsored and financed by the Social Science Research Council, and the Institute of Environmental Sciences, a private research and study organisation. The Environmental Economics Study Group was responsible for the commissioning of the papers that appear in this volume. In addition some of the comments made by conference delegates during discussion time have been included, in edited form, in short sections, following the individual contributions. Two formal 'replies' were also read at the conference and these too are included.

Surprisingly, very few economists in the United Kingdom are actively engaged in the study of natural resource problems. It is to be hoped that this volume will encourage others to investigate this much under-researched area. More important, however, it is to be hoped that the contributions will appeal for their intrinsic value and for the issues they raise. There can be no single 'economic' view of the natural resource problem. The essays in this volume indicate some of the ways in which some economists approach the task.

An immense debt of gratitude is owed to Mrs Jenni Burrow and to Miss Angela Bartoli of the University of Southampton, whose organisational wizardry ensured that the conference took place at all. And to the remaining host of helpers a special word of thanks is due.

D.W.P. 